\title{
ANALYSIS, RECONSTRUCTION AND ESTABLISHMENT OF TOURIST DESTINATIONS IN TOBA SAMOSIR, NORTH SUMATERA, INDONESIA
}

\author{
Menara Simanjuntak; Haryadi Sarjono \\ Management Department, School of Business Management, Binus University \\ menara0110@yahoo.com; haryadi_s@binus.edu
}

\begin{abstract}
This study aimed to provide inputs for local government of Toba Samosir (Tobasa) in preparing strategic development plan of tourist destinations in District Tobasa. This study is a qualitative approach through in-depth interviews and feedback from forum discussion groups with participants representing community leaders, indigenous peoples, governments and travel business. Total participants are 15 people collected on June 1, 2012 at Balige government office. Discussion forums formulated nine locations of tourist destination spread in Toba Samosir. As result this research, we formulated four strategic plans with tactical plans; (1) specifying and establish the location of tourist destinations in the District Tobasa; (2) submitting plans to the government budget or through the budget of Tobasa district in five years starting in 2014 to follow; (3) conducting government financing for infrastructure development and tourism industry participation; (4) doing tourism and cultural promotion. We found limitations for the plan. Some of them were: the low budget provided by the District government so that we expected supports from domestic investors to accelerate tourism development in the area. Most activities were proposed under the action plan of both Tobasa District government and North Sumatra Government..
\end{abstract}

Keywords: tourist destination, tourism strategies, tourism stakeholders, sustainable tourism

\begin{abstract}
ABSTRAK
Penelitian ini bertujuan untuk memberikan masukan bagi pemerintah Kabupaten Toba Samosir dalam mempersiapkan rencana pembangunan strategis tujuan wisata di Kabupaten Tobasa. Metodologi penelitian ini melalui pendekatan kualitatif dengan wawancara mendalam dan rumusan dari kelompok forum diskusi dengan peserta yang mewakili tokoh masyarakat, pemerintah dan kalangan Industri Pariwisata Tobasa, Perguruan Tinggi berjumlah 15 orang pada 1 Juni 2012 bertempat di Kantor Kabupaten Tobasa, Balige. Forum diskusi merumuskan sembilan lokasi tujuan wisata yang tersebar di Toba Samosir. Tim telah merumuskan empat rencana strategis dengan rencana taktis sebagai hasil penelitian ini, yaitu: (1) menentukan dan menetapkan lokasi tujuan wisata di Kabupaten Tobasa; (2) menyerahkan rencana untuk anggaran pemerintah provinsi atau melalui distrik anggaran Tobasa lima tahun mulai tahun 2014 yang akan datang; (3) melakukan pembiayaan pemerintah untuk pembangunan infrastruktur dan partisipasi dari industri pariwisata itu sendiri; (4) melaksnakan promosi budaya. Keterbatasan yang dihadapi adalah anggaran APBD Provinsi sehingga mengharapkan investor domestik untuk mendorong percepatan pembangunan pariwisata di daerah ini. Sebagian besar kegiatan diusulkan melalui rencana aksi Tobasa dari instansi pemerintah Kabupaten lintas sektor dan pemerintah provinsi.
\end{abstract}

Kata kunci: Tujuan wisata, strategi pariwisata, budaya dan adat, stakeholder pariwisata 


\section{INTRODUCTION}

Tobasa district used to cover the area of Toba and Samosir. Further development after Samosir Island became a separated district, the district Tobasa keep using it as an effort to keep the name in memory of the historical relationship. Administrative Region government was Toba Samosir in 2009 consisted of 16 districts with 203 villages and 13 urban villages. The population of Toba Samosir in 2009 was 175. 325 people with 39.339 households. The population density in 2009 was 86.7 people $/ \mathrm{km}$. The people are part of the tribe of Batak Toba. Christian is the majority religion.

Toba Samosir located at 20.03"-20.40" north latitude and 98.056"-99.040" east longitude, on the east side of Lake Toba, a distance of $340 \mathrm{~km}$ from Kualanamu International Airport, Medan. Balige is the capital of Tobasa Distric. The land area of Tobasa is $2021.8 \mathrm{~km}$. Topographically, Tobasa region is mostly hilly and mountainous. Other area is lowland of rice fields around the lake surrounded by mountains. Agricultural area reaches the foot of the mountains and the rest is protected forest area of 122.800 ha, while the conservation of natural forests covers 23800 ha. The hills are mostly planted with pine trees by the Forest Service. However, as much as 17.708 ha of the area is deforested by fire. The remaining forests cover an area of 16.781 ha (Kantor Statistik Kabupaten Tobasa, 2010).

The attractiveness of this region for tourists is the natural scenery of hills towards the lake, beach area and the air temperature is cool enough range between $15{ }^{\circ} \mathrm{C}$ to $21^{\circ} \mathrm{C}$. The surface of Lake Toba is approximately 850 meters above sea level. Poor, there has not been any official tourist destinations publicized by the Government of Tobasa Region. So far Lake Toba is the only famous as tourist destination in Tobasa Distric.

A tourist attraction is a place of interest where tourists visit, typically for its inherent or exhibited cultural value, historical significance, natural or built beauty, or amusement opportunities. Some examples are historical places, monuments, zoos, aquaria, museums and art galleries, botanical gardens, buildings and structures (e.g. castles, libraries, former prisons, skyscrapers, bridges), national parks and forests, theme parks and carnivals, living history museums, ethnic enclave communities, historic trains and cultural events.

Some tourist sites are known to be de facto by the people in the District Tobasa because frequented by domestic and foreign tourists. The location has not been laid out and there has been no official management and no significant physical development, as well as the government has not been communicated to the local community. Tobasa actually owns some potential tourism, such as adventure travel, Agritourism, cultural tourism, dark tourism, garden tourism, rural tourism, safaris, volunteer travel, water tourism, museums, etc. The number of foreign tourists coming to Tobasa is still very low, around 5,000 people in the year 2011, while local tourists reached nearly 200,000 people, especially on school holidays.

Tobasa offers history tourism at Tomb of King Si XII in Soposurun, Batak culture museums at TB Silalahi Centre, water resources and the swimming poll in Hinalang Balige, religious tourism at Tomb of Rev. Dr. I.L.Nommensen, Laguboti (Spreader Christianity in the Batak Land), Lake Toba, Lumban Silintong, dark cave at Liang Sipege, Silaen, water Tourism in Pangkodian and Meat, Tampahan, nature tourism at Dolok Tolong, Hutaginjang and Singgolom, Tarabunga, Tampahan, agritourism at Gurgur Aek Raja, and village and traditional house of Batak (Ruma and Sopo).

The purpose of this study is to provide advice to the Government of Toba Samosir to develop a strategic and technical plan for tourism development. 


\section{METHOD}

This study is a qualitative approach through in-depth interviews and feedback from forum discussion groups with participants representing community leaders, indigenous peoples, governments and Tourism Industry Tobasa. The team visit Tobasa District and arranged discussions with tourism stakeholders, the House of Representatives, The Office of Tourism, and local community leaders as well as some tourism entrepreneurs. Team created SWOT analysis to get recommendations for tourism strategic plan in Toba Samosir. The data obtained directly from the information of Tobasa Government about the activities/ projects that have been done or will be done in 2013.

\section{RESULTS AND DISCUSSION}

\section{Batak Toba's Culture and Customs}

Tobasa society applies traditional culture of Batak Toba in everyday life. In terms of kinship, they rarely call people by their real names but substitute names, such as angkkang for old brother, anggia for young brothers, ito for sisters, amangtua for father's old brother and inangtua for his wife, amanguda for father's younger brothers and inanguda for his wife, tulang for mother's brothers and nantulang for his wife, namboru for father's sister and amangboru for her husband, ompung for grandfathers and grandmothers, and so on.

Each person has a particular clan lineage. Marriage is not allowed for couple under one clan, but with the inter-clan descendants. Therefore, Batak kinship will increasingly broad and will involve many clans. For example, a traditional wedding ceremony may involve more than ten clans, starting from Si Raja Batak who is the first Batak descent to the tenth descendants. Some clans known are Siahaan, Simanjuntak, Hutagaol, Marpaung, Simangunsong, Napitupulu, Pardede, Siagian, Sianipar, Sibarani, Sirait, Manurung, Silaen, Tampubolon, Silitonga, Silalahi and so on.

Dalihan Natolu which means three parties is the relationship with the family of brothers in one lineage, family of sisters, or with the family of the man-in-law in one lineage. Under the framework of these relationships, customs of Batak Toba are performed starting from childbearing, marriage, ceremony of someone's death, until ceremony of collecting the bones of ancestors.

Another genuine culture of batak is Tortor traditional dance. It can be performed either without traditional musical instrument called gondang sabangunan or with a complete set of instrument. Martumba is also a social dance performed by young people accompanied with music hasapi. Batak culture art show can be performed as entertainment in the form of opera about Batak stories, music, song and dance, which has existed since 1945 with duration of about 3 hours. Earlier some opera groups moved from one city to another, but now the revenue was reduced due to the lower interest of public.

\section{Historical Dimension}

Lake Toba has been the main interest of tourist destination due to its historical and cultural uniqueness. Lake Toba and the surrounding topography were made happen by the great eruption of Mount Toba thousand years ago. It then created the Samoris Island surrounded by Lake Toba. Initially, Batak people lived in the mountain Pusuk Buhit near the lake. They are bred and crossed the lake to the Samosir Island. They did hunting, fishing, farming, animal husbandry and so on, which can be proved from the historical artifacts in Museums. The history of Batak Toba and the surrounding 
territory is part of the kingdom Sisingamangaraja I to XII (1200-1907). Previously, they had ruled the kingdom for hundreds of years from generation to generation that can be proved by the writing, language, culture, stamp, flags, and the rules as well as arts and cultural customs that characteristic.

\section{Tourism Planning and Development Dimension}

Department of Tourism and Culture of North Sumatra have been developing culture and art through financing development. However, the budget is very low to be allocated to 32 districts/ cities, so the District Government must rely more on his own sources. Arts and culture infrastructure development includes the construction of training centers of Batak Toba traditional cultural arts, traditional music instruments procurement, training for prospective instructors, training for players, training for dancers, management of culture and customs performance, etc. For now the center of traditional arts and culture at Region level more effectively, while at the district level cultural art workshop developed associated with the development of cultural centers in the Region. Toba Batak cultural performance can indeed be seen briefly on the Bull event each year is centered in Parapat (District Simalungun).

Due to the limited budget of the provincial government, the plan of tourism and culture development strategy must be designed in the long term, medium term and short term. The medium and long term tourism sector is expected to contribute to local revenues to improve the welfare of the people nearby the tourist destinations.

Community stakeholders, including Governments, tourists, hosts, tour operators and other tourism-related business with must assume responsibility for ethics and code of ethics (Fennell, 1999; Herremans \& Welsh, 1999). Decision-making and development process requires a multi-stakeholder involvement at all levels of planning and policy making, Bringing together Governments, NGOs, citizens, industries and professionals in a Partnership That Determines the amount and type of tourism desired by the community.

The stakeholders, Organizations / agencies and planners together to Provide information and education and outreach programs to the community, visitors, industry and other stakeholders in order to increase public and political awareness for planning and conservation of tourism resources of society (Sirakaya et al, 2001 ). Stakeholders must develop a system that can be monitored and adjusted with planning and management purposes.

Local Agenda 21 is the special mandate given to local Governments adopted form the 1992 Earth Summit in Rio de Janeiro as a way to move towards sustainable development (United Nation). The Local Agenda 21 brings this commitment to the local level, allowing each community to set its own path towards sustainable development. At the local level, sustainable development is achieved by steering local development activities to obtain three objectives simultaneously: (1) increasing local social welfare; (2) obtaining greater and more equitably distributed, local economic wealth; (3) enhancing integrity of local Ecosystems.

Analyze tourism and cultural development in District Tobasa should review a variety of important dimensions to be adopted (Fridgen, 2009).

\section{Infrastructure Dimension}

District Tobasa owns a main road as long as $70 \mathrm{~km}$. It has asphalt roads along $120 \mathrm{~km}$ and 200 $\mathrm{km}$ unpaved roads. Several roads around the lake need to be widened for the bus pass, particularly the highway that traces 7-Km shore of Lake Toba, ranging from Balige to Meat, Tampahan. 
Accomodation and transportation are some of major supports for tourism industry. There are 400 rooms available for rent in Balige and Laguboti. 10 Lodging Houses are spread out in several city districts with a capacity of 500 rooms. There is also an intern ational standard resort and luxury facilities with a capacity of 50 rooms in Tarabunga village, Tampahan. Several villages potentially serve as a cultural tourism because it still has a lot of indigenous heritage houses like Ruma and Sopo, although most require renovation. Ruma is the official residence of the Batak family, while Sopo is a place to live integrated with a rice barn and the beams are made larger than the traditional house. However, there is only one on-site gazebo at Pagarbatu Soposurung Balige. It makes difficult for tourists to get a toilet and drink water. Additionally, the transportation acrossing the Samosir Island takes a 2-hour trip. Other facilities like docks for coastal tourism destinations have been inadequate to serve boat riding.

The air transportation to North Sumatra was moved from Polonia International Airport in Medan to Kualanamu International Airport around $10 \mathrm{~km}$ from Medan. To get to Balige, tourists need to continue with a 4-hour road trip or take another flight from Polonia airport with a small plane. Susy Airlines serves the flight for at least 20 people with ticket price Rp.300.000 per pax. Tourists from Malaysia and Singapura can go directly to Tobasa Distric from Silangit Airport located on the border of North Tapanuli and Tobasa District with small planes with a capacity of 25 passengers. Another alternative is through Sibisa airport in Parapat which borders the Tobasa District using small planes. There are some golf courses nearby the airport. Another potential to development is ex Dai Nippon Airport at Samosir Island which can manage a 25-passenger plane after a renovation. The air transportation development is very potential to take tourists from neighboring countries such as Singapore, Malaysia, and Thailand to Lake Toba. Entrance of tourists by road is through Parapat, Rantau Prapat by Aek Kanopan, Padang Sidempuan through Sipirok and the Sibolga seaport passing Tarutung, and passing through the port of Belawan, Medan and Parapat.

Tourism infrastructure also includes a variety of facilities such as restaurant, health clinics, police stations, shipping companies, international dial telephones, first aid officers (rescue team), etc. Additionally, international food shall be available for international tourists who are not familiar with local food. It will stimulate the growth of culinary industry.

As noted, the development of infrastructure especially road infrastructure is expected to integrate with other development targets such as the agricultural sector associated with the mission of tourism as Agritourism, as well as a means of transportation between districts and villages to stimulate economic growth in the District Tobasa.

\section{Economic Dimension}

Tourism is an interesting industry because of its ability to create revenue, taxes, currency movements and a high turnover in various forms and the work has provided a significant economic contribution to society in various countries around the world. Entering the 21st century, the globalization of capital or investment, population mobility and advancement in the field of transportation and information technology has encouraged the tourism industry into one of the largest industries in the world (Sirakaya \& Choi, 2001).

Tourism sector in various countries in the world is an opportunity to earn income and foreign exchange, so that various attempts should be made by a State to invite tourists into the country. Indeed, the return on investment on tourism infrastructure is in the long term, so that the local government should provide guarantees to investors, including the ease of permitting the construction of tourism infrastructure. 
The average growth of Tourism Industry in Indonesia today is about 10 percent. Foreign tourist visiting North Sumatra and District Tobasa are mostly from Singapore and Malaysia. The average expenditure of foreign tourists is USD 100 per day. If the hotel and transportation infrastructure to the destination location are sufficient to serve the tourists, it will increase the tourists' interest to visit Lake Toba.

Tourism sector as a source of income for individuals, communities and the tourism industry is expected to remain within the context of Agenda 21: Sustainable Tourism Development which is emphasized on improving the welfare of local people. That is why intensive communication with local communities is needed so that they can immediately take their position for the tourism development in their region. In general, community involvement in the economy on small and medium scale enterprises such as building homestays, opening shops, opening restaurant, and operating transportation in the destination locations.

\section{Social and Cultural Dimension}

In several lastest decades, Tobasa has been familiar and accustomed to foreigners visit as tourists. Many people in Indonesia said that Batak people are scary. However, thier hospitality in welcoming guests is very well. No wonder many foreign tourists are curious about the social life and culture of the Batak people. They want to see not only the people working in the fields, but also people fishing and they want to stay in the village for a week. If there is a custom event, they want to watch from start to finish. In Tomok, tourists can get offers from guides to explain the object of attention to them. In addition they also get an explanation of cultural differences in the local community with foreign countries.

\section{Environment Dimension}

Tourism brings economic benefits, but leaves some negative impact on environment. An unplanned tourism will bring unwanted side effects that require conservation efforts. Solution to use natural resources better devoted to people's lives better in the economic development of short and long term (Richard \& Hall, 2000).

The isues most highlighted by International Council for Local Environmental Initiatives (ICLEI), and, Commission on Sustainable Development are environmental destruction at tourist destinations in the World and the absence of intensive conservations. Therefore, agenda 21 brings environmental preservation campaign (Fennell, 1999). The environmental problems of District Tobasa are varied such as deforestation, hill fires and illegal logging, Toba lake water pollution, unorganized surroundings of tourist destination, etc. Lake and beach clean-ups have been done, but to eliminate the water pollution from garbage needs the cooperation with the people, which can not be managed quickly. Preserving environment not only brings beautiful views, but also helps improve public's health.

\section{Marketing Strategic Dimension}

Tourists can easily plan a holiday with information support from friends or the internet. One strategy to gain more interest from tourists is supporting a variety of information about holiday budgeting for consideration, such as costs for freight, lodging, meal, enterance fee, souvenirs, and shipping charges. Tourists can choose to visit Tobasa alone, with family or with a group with a variety of transportation means such as aircraft, cars and buses. Homestay accommodation from regular hotel or resort and lodging should be wildely informed. Eventually, promoting tourist destination to international market needs support from Government. For example is a promotion through cultural performances to Malaysia and Singapore as the largest tourist source country to Lake Toba. 


\section{Proposed Strategic Plans}

After doing a SWOT analysis of strengths, weaknesses, opportunities and threats of various dimensions using balance score card for determining the location of tourist destinations in Tobasa, we proposed strategic and operational plans for multi years implementation as follows: First is specifing and establishing the location of tourist destinations in the District Tobasa by carrying out complete coordination meetings with stakeholders, communication activities with the community of tourist destination, asking local regulations regarding the determination of the location of a tourist destination, restructuring plan in each location a tourist destination as spatial planned. Second is submitting plans to the province government budget or the district budget of Tobasa by the follwing processes: (1) accumulating development discussion proposals from the village, district and county; (2) consultating with the provincial planning; (3) consolidating the budget proposals with the District Tobasa sector of agricultural and public construction. Third is managing government financing for infrastructure development and participation of the tourism industry by the following processes: (1) implementing the development plan and consultation for develop tourist destination; (2) establishing the implementation of tourist destination development; (3) setting road construction site of tourist destination; (4) issuing permits for tourism industry infrastructure development; (5) establishing guidelines for community participation in tourism industry; (6) monitoring and evaluatiing. Fourth is doing tourism and cultural promotion by the following processes: (1) building a tourism website for Tobasa District; (2) joining the provincial tourism promotion on national level; (3) doing exhibition of Toba Batak culture in Malaysia and Singapore.

\section{CONCLUSION}

Increasing public welfare of Tobasa does not enough if only rely on income from agricultural sector. Meanwhile, the wealth of Tobasa in other sectors such as natural, historical, social, cultural and artistic has not been managed well. Tobasa communities need a breakthrough to increase thier welfare by utilizing tourism sector. Tobasa Goverment is suggested to build partnerships with leaders of community, religions and politic around the site of tourist destinations in planning and implementing development tourism. Additonally, they should actively promote the local tourism in national and international levels.

\section{REFERENCES}

Fennell, David A. (1999). Ecotourism: An introduction. New York: Routledge.

Fridgen, Joseph D. 2009, Dimension of Tourism. Texas: Culinary and Hospitality Industry Publications Services.

International Council for Local Environmental Initiatives (ICLEI). (1999). Sustainable Tourism Development: A Local Authority Perspective. New York: Commission on Sustainable Development Seventh Session.

Kantor Statistik Kabupaten Tobasa. (2010). Kabupaten Tobasa dalam Angka. Balige: BPS Toba samosir.

Richard, G., and Hall, D. (2000). Tourism and Sustainable Community Development. New York: Routledge. 
Sirakaya, Jamal, \& Choi. (2001). Developing tourism indicators for destination sustainability. The encyclopedia of ecotourism, 411-432.

United Nation. Tourism and Local Agenda 21. Accessed from http://www.unep.fr/shared/publications/pdf/3207-TourismAgenda.pdf. 